\title{
EFFECT OF SEQUENCE OF PREGNANCY ON LITTER SIZE AND GROWTH IN PEROMYSCUS POLIONOTUS*
}

\author{
R. G. WILLIAMS, J. L. GARMON AND F. B. GOLLEY \\ Department of Experimental Statistics, University of Georgia, \\ Athens, Georgia, U.S.A.
}

(Received 24th October 1964)

\begin{abstract}
Summary. An analysis of 143 litters of Peromyscus polionotus showed that litter size increased by 0.30 mice/litter up to the fourth pregnancy. After the fourth litter, litter size increased at a lesser rate to the sixth pregnancy.

Growth followed the same general pattern as did litter size. The effect of order of litter was significant for weights up to 28 days of age. In general, average weight of the mice increased up to the sixth pregnancy and then decreased.
\end{abstract}

Litter size and growth of laboratory mice (Mus musculus) are influenced by a variety of environmental and genetic factors including the number of the litter in the sequence of pregnancies of an individual female. Bittner (1936) presented data which showed a maximum litter size at the third litter. Grüneberg (1952) summarized the data of Bittner from several inbred lines of mice, in which relatively small first litters were followed by an increase to a plateau in litter size and a final period of decline. Biggers, Finn \& McLaren (1962) reported a similar relationship of litter size to litter order in eighteen normal mice and twenty-two mice in which one ovary had been removed before sexual maturity. Evidence that other litter-bearing animals follow this general pattern has been presented by King (1916) and Asdell, Bogart \& Sperling (1941) in rats (Rattus norvegicus) and by Lush \& Molln (1942), Olbrycht (1943) and Pomeroy (1960) in the sow (Sus scrofa). Generally the decline of litter size in the sow is slower than in the mouse or rat.

In addition to the effect of sequence of pregnancy on litter size in these species, there is also a functional relationship between sequence of pregnancy and milk production. For instance, Smith (1952) has shown that, as sows become older, milk production increases to a maximum and then declines. Maximum milk production is reached in sows at approximately 4 years of age. Further, sows which farrow the largest litters produce the most milk. Allen \& Lasley (1960) reported a highly significant positive correlation between milk production and size of litter suckled. These authors related the increased milk production to

* Journal Paper No. 391 of the College Experiment Station of the University of Georgia, College of Agriculture Experiment Stations. This research was supported in part by Atomic Energy Commission Contract AT (40-1)2975. 
more functional nipples in larger litters. Thus, litter size and milk-producing capacity are often expressed as a common function in the sow. Similar correlated responses of litter size and milk production have been discussed by Snell (1956).

The information on the effect of sequence of pregnancy in litter-bearing mammals has been obtained on species which have been selected through generations for docility, production of young and other characteristics. We cannot be completely certain that the effect demonstrated for domestic animals will apply to wild species, since under free-living conditions the length of life is usually quite short (for an animal the size of a laboratory mouse it is approximately 6 months) and large litters early in the reproductive life might be advantageous to the species. For this reason, we have investigated the long-term reproductive performance of Peromyscus polionotus, the old-field mouse (deer

TABLE 1

MEAN NUMBER OF MICE BORN ACCORDING TO ORDER OF PREGNANCY

\begin{tabular}{c|c|c}
\hline Order of pregnan:y & Litter size & s.e. \\
\hline 1 & $3 \cdot 33$ & $0 \cdot 11$ \\
2 & $3 \cdot 54$ & $0 \cdot 15$ \\
3 & $3 \cdot 94$ & $0 \cdot 22$ \\
4 & $4 \cdot 10$ & $0 \cdot 29$ \\
5 & $4 \cdot 12$ & $0 \cdot 35$ \\
6 & $4 \cdot 30$ & $0 \cdot 40$ \\
7 & $4 \cdot 00$ & $0 \cdot 36$ \\
\hline Overall mean & $3 \cdot 90$ & \\
\hline
\end{tabular}

mice), to determine the effect of pregnancy order on litter size and growth of the young. Old-field mice are one of the most abundant small mammals in abandoned crop fields in the south-eastern United States.

The parent population of mice and the method of husbandry has been described by Carmon, Golley \& Williams (1963). Data were collected on 143 litters produced by the first generation offspring from the parent population, trapped at the United States Atomic Energy Commission's Savannah River Plant, Aiken, South Carolina, during the summer of 1962. Because it was impossible to determine the age of the original trapped parents, the data from these females were not used in the analysis.

A standard least-square analysis of variance was used to analyse the data. Mean separation was by the method of Harvey (1960). Additive models were used, taking into account parity and random error in the analysis of litter size; and parity, sex, litter size and random error in the analysis of body weight at the various ages.

Significant differences $(P<0.05)$ in litter size among pregnancies were observed. As noted in Table 1, litter size increased sharply over the first three litters and at a slower rate for the next three litters. Although not significant, a decline in litter size was noted for the seventh litters. 
Evidence of large maternal effects on body weights of this species from birth up to weaning has been presented by Carmon \& Golley (1964). Thus it is important to ascertain the significance of the effect of sequence of pregnancy on body weight at various ages. The mice were weighed individually at weekly intervals for the first 6 weeks of life. Litter size had a significant effect on body weight at all ages; the effect of sex was only significant after 4 weeks, and the effect of the number of the pregnancy was significant up to weaning (at 3 weeks), but not thereafter. Carmon et al. (1963) in an analysis of the offspring of the parent stock of these mice also found that sex effects were not significant until 28 days.

The mean weights, adjusted for sex and litter size, are shown in Table 2. In general the mean weight increased up to pregnancy six for the first four weight periods. Thus, the weights up to weaning are influenced in the same general pattern as litter size by sequence of pregnancy. The gradual increase in average

TABLE 2

ADJUSTED MEANS FOR WEIGHTS IN GRAMS LIVE WEIGHT

\begin{tabular}{l|c|c|c|c|c|c|c}
\hline & Birth & 7 days & 14 days & 21 days & 28 days & 35 days & 42 days \\
\cline { 1 - 4 } Pregnancy 1 & 1.54 & 3.24 & 4.88 & 6.96 & 8.97 & 10.72 & 11.87 \\
Pregnancy 2 & 1.63 & 3.45 & 5.02 & 6.82 & 9.22 & 11.05 & 12.34 \\
Pregnancy 3 & 1.74 & 3.54 & 5.22 & 7.56 & 9.50 & 11.14 & 12.27 \\
Pregnancy 4 & 1.76 & 3.78 & 5.26 & 7.72 & 9.49 & 11.47 & 12.90 \\
Pregnancy 5 & 1.83 & 3.67 & 5.18 & 7.60 & 9.94 & 11.50 & 12.48 \\
Pregnancy 6 & 1.74 & 3.95 & 5.60 & 7.92 & 9.33 & 11.75 & 12.28 \\
Pregnancy 7 & 1.84 & 3.90 & 5.18 & 7.10 & 9.06 & 10.75 & 11.73 \\
\hline Overall mean & 1.73 & 3.65 & 5.19 & 7.38 & 9.36 & 11.02 & 12.27 \\
\hline
\end{tabular}

weight as litter number increases could be a reflection of increased milk production since adjustments were made for differences in litter sizes. In turn the increased milk production is believed to be related to increased litter size and progressive physiological maturity as has been shown by Smith (1952) and Snell (1956).

\section{REFERENGES}

Allen, A. D. \& Lasley, J. D. (1960) Milk production of sows. F. Anim. Sci. 19, 150.

Asdell, S. A., Bogart, R. \& Sperling, G. (1941) The influence of age and rate of breeding upon the ability of the female rat to reproduce and raise young. Mem. Cornell Univ. agric. Expt. Sta. No. 238.

Biggers, J. D., Finn, C. A. \& McLaren, A. (1962) Long-term reproductive performance of female mice. II. Variation of litter size with parity. F. Reprod. Fertil. 3, 313.

BITTNER, J. J. (1936) Differences observed in an inbred albino strain of mice following a change in diet. I. Litter size. Fackson Memorial Lab. nutr. Bull. 2, 3.

Garmon, J. L. \& Golley, F. B. (1964) Factors affecting weights in Peromyscus polionotus. Growth, 28, 105.

Carmon, J. L., Golley, F. B. \& Williams, R. G. (1963) An analysis of growth and variability in Peromyscus polionotus. Growth, 27, 247.

Grüneberg, H. (1952) The genetics of the mouse, 2nd edn. Nijhoff, The Hague.

HARveY, W. R. (1960) Least-square analysis of data with unequal sub-class number. USDA, ARS. $20-8$.

KING, H. D. (1916) The relation of age to fertility in the rat. Anat. Rec. 11, 269.

Lush, J. L. \& MolLn, A. E. (1942) Litter size and weight as permanent characteristics of sows. USDA Tech. Bull. No. 836. 
OlbRycht, T. M. (1943) The statistical basis of selection of animal husbandry. II. Studies on life performance of brood sows: the judging of brood sows by their number of offspring born and reared in the earliest litters. J. agric. Sci. $33,74$.

Pomeroy, R.W. (1960) Infertility and neonatal mortality in the sow. I. Lifetime performance and reason,

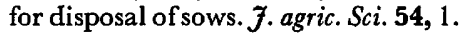

Smith, W. W. (1952) Pork production. Macmillan, New York.

SNELL, G. D. (1956) Biology of the laboratory mouse. Dover Publications, New York. 